\title{
Are CEO experience and financial expertise associated with financial restatements?
}

\author{
Zabihollah Rezaee $^{a}$, Kaveh Asiaei ${ }^{b}$, Toktam Safdel Delooie
}

a) Fogelman College of Business and Economics, University of Memphis, United States of America.

b) Department of Accounting, Faculty of Business \& Accountancy, University of Malaya, Kuala Lumpur, Malaysia.

c) Faculty of Economics and Administrative Sciences, Ferdowsi University of Mashhad, Mashhad, Iran.

\author{
${ }^{b}$ Corresponding author. \\ E-mail address: kaveh@um.edu.my
}

\section{A R T I C L E I N F O}

\section{Article history:}

Received 23 May 2019

Accepted 15 April 2020

Available online 1 July 2021

\section{JEL classification:}

M14

M41

Keywords:
Corporate governance

CEO succession

CEO succession

CEO financial expertise

Financial reporting quality

Financial restatement

\section{A B S T R A C T}

This study examines whether and how Chief Executive Officer (CEO) experience and financial expertise affect financial restatements (FR) by investigating a sample of Iranian listed companies from 2008 to 2017 We define experienced CEOs as those who are hired from inside the firm and financial expert CEOs as those who hold an accounting qualification or have work experience as an auditor, chief financial officer (CFO), controller, and or other accounting-related positions. We find that FR is positively associated with insider CEOs (CEOs with more internal experience), and negatively associated with CEO financial expertise. Moreover, we find that CEO experience is negatively associated with FR when the CEO is a financial expert. This result highlights the importance of financial background for senior executives. Further, our results show that insider CEOs can improve the financial reporting quality through reducing FR when they have higher decision-making power. This study contributes to the literature on CEO characteristics and financial reporting. The results provide important implications for policymakers and the board of directors in emerging economies regarding the requirement to appoint top managers with financial expertise.

(C)2021 ASEPUC. Published by EDITUM - Universidad de Murcia. This is an open access article under the CC BY-NC-ND license (http://creativecommons.org/licenses/by-nc-nd/4.0/).

¿Existe asociación entre la experiencia del director general y los conocimientos financieros con las reformulaciones financieras?

R E S U M N

Este estudio examina si la experiencia del director general (CEO) y los conocimientos financieros afectan a las reformulaciones financieras (FR), y cómo lo hacen, investigando una muestra de empresas iraníes que cotizan en bolsa entre 2008 y 2017. Definimos a los consejeros delegados con experiencia como aquellos que son contratados desde dentro de la empresa y a los consejeros delegados expertos en finanzas como aquellos que poseen una cualificación contable o tienen experiencia laboral como auditor, director financiero (CFO), controlador u otros puestos relacionados con la contabilidad. Encontramos que FR está positivamente asociado a los CEOs con información privilegiada (CEOs con más experiencia interna), y negativamente asociado a la experiencia financiera del CEO. Además, encontramos que la experiencia del CEO se asocia negativamente con FR cuando el CEO es un experto financiero. Este resultado pone de manifiesto la importancia de la experiencia financiera de los altos ejecutivos. Además, nuestros resultados muestran que los directores generales con información privilegiada pueden mejorar la calidad de la información financiera reduciendo FR cuando tienen mayor poder de decisión. Este estudio contribuye a la literatura sobre las características de los directores generales y la información financiera. Los resultados ofrecen importantes implicaciones para los responsables políticos y los consejos de administración de las economías emergentes en lo que respecta a la exigencia de nombrar a altos directivos con conocimientos financieros.

(C)2021 ASEPUC. Publicado por EDITUM - Universidad de Murcia. Este es un artículo Open Access bajo la licencia CC BY-NC-ND (http://creativecommons.org/licenses/by-nc-nd/4.0/). 


\section{Introduction}

Restatement signifies that previously published financial statements are not correct or reliable (Wilson, 2008). Prior research suggests that financial restatement (FR) could be a sign of weakness in the accounting and financial reporting system, ineffectiveness of the internal controls, or a result of management efforts to manipulate the earnings through accounting methods (Akhigbe, Kudla \& Madura, 2005; Agrawal \& Chandha, 2005; Plumlee \& Yohn, 2010). Drawing primarily upon the upper echelons theory, prior research suggests that managerial background characteristics are the underlying determinants of top managers' decisionmaking, financial reporting processes, and organizational outcomes in general (Hambrick \& Mason, 1984; Hambrick, 2007; Bamber, John \& Wang, 2010; Jiang, Zhu \& Huang, 2013; Baatwah, Salleh \& Ahmad, 2015; Custodio \& Metzger, 2014; Gounopoulos \& Pham, 2018; Brockman, Campbell, Lee \& Salas, 2019). More specifically, it has been argued that hiring CEOs with more internal experience results in greater future performance (Brockman et al. 2019). In the same vein, the literature shows that financial expertise enhances CEO ability, which, in turn, leads to an improvement in corporate performance (Custodio \& Metzger, 2014). However, empirical evidence concerning the effect of CEO experience and financial expertise on the FR is sparse, particularly in emerging economies. Therefore, we focus on the two characteristics of the CEO (experience and financial expertise), and examine their effects on the incidence of FR.

The Iran context is well-suited to this paper for two main reasons. First, Iran, as one of the growing economies, has often been criticized for weak corporate governance mechanisms and weak demand for high-quality audit services (Bagherpour, Monroe \& Shailer, 2014; Mashayekhi \& Bazaz, 2008), which could lead to increased financial reporting weaknesses and audit failure that may result in FR (Akhigbe et al., 2005; Czerney, Schmidt \& Thompson, 2014). Second, recent studies in Iran (e.g., Oradi \& Izadi, 2019) indicate that a high percentage of companies restate their financial statements in order to correct accounting mistakes. Thus, whether and how the CEO characteristics affect FR in Iran is an important question that could have implications for other emerging economies and markets.

We hand-collect information concerning CEO characteristics that is relevant to experience and financial expertise and examine its link to the incidence of FR. Following the prior literature on CEO succession (e.g., Brockman et al., 2019), we consider insider CEOs using an indicator variable equal to one if the CEO is hired from inside the firm, and zero otherwise. Furthermore, consistent with prior research, we define financial expert CEOs as those who hold an accounting qualification, or have work experience as an auditor, CFO, controller, and or other accounting-related position (e.g., Custodio \& Metzger, 2014; Baatwah et al., 2015; Kalelkar \& Khan, 2016).

After controlling for other FR-related factors, our logistic regression results show that FR is positively associated with insider CEOs (CEOs with more internal experience), and negatively associated with CEO financial expertise. Moreover, we find that CEO experience is negatively associated with FR when the CEO is a financial expert. Further, our results show that insider CEOs can improve the financial reporting quality through reducing FR, when they have higher decisionmaking power.

This study contributes to the literature in several ways.
First, we expand the literature on CEO characteristics and financial restatements. Prior research examines the relationship between CEO characteristics, such as CEO overconfidence (Presley \& Abbott, 2013) and CEO age (Huang et al., 2012), and FR, whereas this study is the first to provide evidence regarding the effect of CEO experience and financial expertise on the incidence of FR in an emerging market. Second, this study adds to the literature on the manager fixed effects, similar to the studies of Bamber et al. (2010) on voluntary disclosures, and that of Demerjian, Lev \& Lewis (2013) on financial reporting quality. Third, we address the importance of CEO characteristics, and, specifically, CEO financial expertise in the corporate governance structure that is considered relevant in prior restatement research (e.g., Abbott et al., 2004; Carcello et al., 2011; Abbott et al., 2012; Habib \& Hossain, 2013). Fourth, we contribute to studies that examine the determinants and consequences of FR including financial reporting quality (Palmrose \& Scholz, 2004), the reduced firm value (Palmrose \& Scholz, 2004), higher cost of capital (Bardos \& Mishra, 2014), negative stock price reaction (Wilson, 2008; Chen et al., 2014), higher litigation risk (Palmrose \& Scholz, 2004; Bardos \& Mishra, 2014), and an increase in CEO/CFO turnover (Hennes et al., 2008).

Finally, this study provides policy and practical implications by suggesting that regulators, standard-setters, and the board of directors in emerging economies pay attention to the importance of financial expertise in establishing corporate governance measures and financial standards for appointing CEOs. Our results provide insights into (1) hiring financial expert CEOs that could build up the trust of accounting information users, particularly in the emerging markets; and (2) the decision of whether to replace a CEO by an insider or outsider in light of not only firm performance measures but also the contribution to the financial reporting quality of the firm.

The remainder of the paper is structured as follows. The second section presents the related literature and develops the research hypotheses. The third section provides a discussion of the sample and research design. The fourth section presents the findings of the descriptive analysis, univariate analysis, and multivariate analysis, as well as the results from several supplementary analyses. The final section summarizes the concluding remarks and discusses possible implications.

\section{Related literature and hypothesis development}

\subsection{Related literature}

Restatements signify the low quality of financial reporting and misstatements of prior financial reports (General Accounting Office, 2002). Audited financial statements are often restated when the following four conditions are met: (a) existence of material misstatements in the published financial statements (e.g., aggressive accounting practices of the management, misapplication of the accounting principles and practices); (b) misstatements are not detected and prevented by the internal controls; (c) the external auditor failed to detect the misstatements and financial statements are issued; and (d) the misstatements are detected after financial statements were published, and, if they are significant, companies will be required to correct, restate, and reissue financial statements (Eilifsen \& Messier, 2000). According to previous studies, the determinants of FR can be classified in five groups: (a) environmental structure and firm character- 
istics, such as firm size, profitability, age, financial distress, and internal control weaknesses (e.g., Beasley, 1996; Abbott et al., 2004; Almer et al., 2008; Plumlee \& Yohn, 2010); (b) managerial characteristics and corporate governance structure, such as independent boards of directors, absence or deficiency of the audit committee, CEO duality, and the expertise of financial managers and employees (e.g., Beasley, 1996; Abbott et al., 2004; Aier, Comprix, Gunlock \& Lee, 2005); (c) ownership structure (e.g., DeFond \& Jiambalvo, 1991; GAO, 2002; Jiang, Habib \& Zhou 2015); (d) accounting standards, such as the increase in complexity of standards and rules of accounting and reporting (e.g., GAO, 2002; Plumlee \& Yohn, 2010); and (e) the audit quality of financial statements (e.g., Chin \& Chi, 2009). In the present study, we focus on the factors related to the second group regarding the top managers' characteristics and review the association between the experience and financial expertise of the CEO and the incidence of FR.

A general viewpoint in prior corporate governance and accounting research is that CEOs may use resources for their own interests and disregard investors' interests (e.g., Jensen \& Meckling, 1976; Beasley, 1996; Klein, 2002), and may misstate financial reports to achieve their own interests (Ali \& Zhang, 2015). In addition, prior research suggests that FR is an indicator of earnings management practices (Agrawal \& Chandha, 2005). The stakeholder theory, which is a synthesis of organizational and social theories, highlights the importance of the management leadership role in strategic decisionmaking (Hambrick \& Mason, 1984). According to the upper echelons theory, strategic choices of CEOs, who hold the most powerful position of an organization, are based on their background and functional experiences (Crossland \& Hambrick, 2007). On the grounds that CEO ideals form their managers' leadership practices, a firm's tendency to meet stakeholder demands is highly likely to be affected by the main decisionmakers' beliefs and value systems (Huang, 2013). Accordingly, it could be expected that CEOs significantly affect firm issues, such as financial reporting, because improving the financial reporting quality engenders investors' trust and increases the number of investors in the company, thereby enhancing firm value.

Consistent with this, prior research shows that CEO characteristics could affect organizations' outcomes and financial reporting (e.g., Francis et al., 2008; Bamber et al., 2010). Specifically, Bamber et al. (2010) claim that CEO characteristics can be used to predict the effect of a CEO on financial reporting, because these characteristics play a major role in forming CEO behavior. Collectively, recent literature on the financial reporting quality points to the significance of CEO demographic characteristics in preventing accounting mistakes, and, thus, safeguarding shareholders' interests (Baatwah et al., 2015).

As discussed earlier, the literature on the effects of top management backgrounds on accounting choices is mainly based on the upper echelons theory, which assumes that managerial characteristics (e.g., experience and financial expertise) may influence corporate performance and financial reporting processes (Hambrick \& Mason, 1984; Hambrick, 2007; Gounopoulos \& Pham, 2018; Campbell et al., 2019). Other studies suggest that CEO characteristics affect FR. For example, Zhang et al. (2018) find that tournament incentives reduce the incidence of $\mathrm{FR}$ and the negative association between tournament incentives, and that FR is related to CEO turnover and is stronger if the successor CEO is recruited from within the firm. Presley \& Abbott (2013) find that overconfident CEOs report more aggressively and increases the likelihood of the incidence of FR. Other factors shown to be related to FR include CEO duality (e.g., Abbott et al., 2012) and CEO age (Huang et al., 2012). Overall, this stream of literature suggests that CEO characteristics affect FR. Nonetheless, two CEO characteristics that are still unexplored in the context of FR are how CEO experience and financial expertise affects financial restatements, which are addressed in this study.

\subsection{Hypothesis development}

Management is primarily responsible for fair and true presentation of financial reports in conformity with a set of globally accepted accounting standards. Thus, both CEOs and CFOs play an important role in assuring high-quality financial reports. CEO succession, as one of the most important challenging roles of the board, is a process in which the board of directors arranges to transfer management to the CEO successor. Kotter (1982) states that CEOs who are internally recruited, compared to outsider CEOs, have a broader knowledge of products, employees, suppliers, and corporate culture and environment. Moreover, CEOs who spent more time in the firm before being appointed as a CEO develop a better relationship with subordinate main managers, and, thus, can receive more honest feedback when they are faced with internal problems (Brockman et al., 2019). Moreover, from the perspective of the stewardship theory, executives hired from within consider themselves as a component of the firm and tend to fulfill the responsibilities that are attributed to them by corporate owners (Ahamed \& Tripathi, 2018). Furthermore, the previous experience of managers can reflect their psychological tendency and abilities, such as values, recognitions, skills, and knowledge (Hambrick \& Mason, 1984). This shows that insider CEOs with past experience have wider knowledge of the internal control structure and are able to mitigate the risk of likely mistakes by overcoming internal control weaknesses.

On the other hand, outsider CEOs have proven to be versatile, which helps them perform better in their managerial functions in the modern business environment (Kaplan \& Minton, 2012). Top managers, with longer tenure due to the social processes in the organization, are more likely to take narrow views, display psychological commitment to the status quo (Hambrick, Geletkanycz \& Fredrickson, 1993), and reduce the quantity and quality of information processing (Tushman \& Romanelli, 1985). In addition, executives with longer organizational tenure, due to their psychological commitment to the status quo and certain social relationships in the company, are not inclined to make the required changes in their organizations (Wiersema \& Bantel, 1993), which could affect firm performance and financial reporting. Moreover, the resource dependence (Pfeffer \& Salancik, 1978) and upper echelons (Hambrick \& Mason, 1984) theories lay great emphasis on the advantages of recruiting CEOs from outside the firm and industry. The theoretical and adaptive perspective of resource dependence supports the external succession of top management as a solution for organizational problems, such as weak performance (Datta \& Guthrie, 1994). Prior research further demonstrates that the increase in CEO experience arising from longer tenure in the firm, is associated with the increase in internal control weaknesses (Lin, Wang, Chiou, \& Huang, 2014) and that this could enhance the likelihood of financial restatements (Plumlee \& Yohn, 2010).

Brockman et al. (2019) found that insider CEOs are more likely to provide a more thorough management fore- 
cast. Brockman, Krishnan, Lee \& Salas (2019) suggest that the CEO in-house experience plays an important role in mitigating audit risk in firms with poor corporate governance quality. Oradi, Asiaei \& Rezaee (2020) show that the effect of CEO financial expertise on the effectiveness of internal controls is stronger if the CEO is recruited from inside the firm. In particular, Karaevli (2007), by reviewing 50 empirical studies on the consequences of executive succession, stated that the findings about post-succession performance are mixed and that the question of whether executive succession (insider vs. outsider CEOs) improves or weakens the corporate performance remains unanswered. According to a meta-analysis conducted by Schepker, Kim, Patel, Thatcher \& Campion (2017), inside CEOs may improve long-term performance and engage in less strategic change, while hiring an outside CEO leads to more strategic change that results in lower long-term performance.

Brockman et al. (2019) suggest that hiring CEOs from within leads to greater future performance, due to the fact that insider CEOs are better aware of corporate activities, such as products, production chain, operations, business situation, and firm culture. Thus, it is expected that insider CEOs are associated with the improvement of corporate performance and financial reporting quality. On the other hand, Zhang (2009) contends that top managers who have greater knowledge and longer tenure may display an extreme commitment to their experience of running their company and take a conservative attitude to changes that can finally worsen the corporate performance. Based on some studies, outsider CEOs have proven to be versatile, which helps them perform better in their managerial functions in the modern business environment (Kaplan \& Minton 2012). However, Jongjaroenkamol \& Laux (2017) indicated that in the cases of firms with outsider CEOs, mistakes and poor performance of management are of grave concern. Overall, according to the foregoing theoretical tensions, insider CEOs may be negatively or positively associated with corporate performance and financial reporting quality. Based on this discussion, the hypothesis is as follows (in alternative form):

H1: There is an association between CEO experience (insider vs. outsider CEOs) and the incidence of financial restatement.

In recent years, firms display a greater tendency to hire financial expert CEOs (e.g., Cullinan \& Roush, 2011; Jiang et al., 2013). Kalelkar \& Khan (2016) consider the recent accounting scandals and increased concentration on the financial reporting in the post-SOX 2002 as being among the reasons for the accelerating trend towards the recruitment of financial expert CEOs. The SOX Act mandates tough conditions for implementing the stewardship role of the board of directors and executives to improve the quality of financial information disclosure as well as auditors to pay special attention to financial restatements for the ultimate purpose of rebuilding public trust and investor confidence in the financial and audit processes (Rezaee \& Fogarty, 2019). The financial expertise can increase CEO performance, especially their role in financial reporting and internal controls (Salehi, Lari \& Naemi, 2018). CEOs with financial expert mitigate corporate weak performance risk and failure risk (Custodio \& Metzger, 2014). Financial expert CEOs also show a more conservative way of performing (Matsunaga, Wang \& Yeung, 2013). Furthermore, financial expert CEOs are more likely to perceive to what extent financial disclosure could help reduce information asymmetry between firms and investors, and facilitate the assessment of firm value for the market participants (Matsunaga \& Yeung, 2008).

Recently, Oradi et al. (2020) find that there is a significant negative association between CEOs with financial expertise and internal control weaknesses. Ettredge, Li, Wang \& Yang (2018) find that financial expert executives reduce the information asymmetry in the initial public offering. Kalelkar \& Khan (2016) report that the financial expertise of CEO lowers audit fees. Baatwah et al. (2015) show that the financial expertise of CEOs reduces the audit report lag. This implies that financial expertise enhances CEO ability to reduce material mistakes and mitigates audit risk. Furthermore, Aier et al. (2005) show that companies have higher earnings quality if their CEOs have had more years of work experience as CFOs. In addition, previous studies showed that financial expert CEOs, compared to their peers who lack financial expertise, have high disclosure quality (Matsunaga \& Yeung, 2008) and are less likely to engage in earnings manipulation (Jiang et al., 2013; Gounopoulos \& Pham, 2018). In summary, prior research suggests that the financial expertise of CEOs reduces firm failure and increases profitability (Custodio \& Metzger, 2014), improves financial reporting quality (Jiang et al., 2013; Gounopoulos \& Pham, 2018), reduces internal control weaknesses (Oradi et al., 2020), and mitigates the audit risk (Baatwah et al., 2015; Kalelkar \& Khan, 2016). In light of this literature, we predict that financial expert CEOs reduce the likelihood of the incidence of FR. Thus, our second hypothesis is as follows (in alternative form):

H2: There is an association between CEO with financial expertise and the incidence of financial restatement.

\section{Research design}

\subsection{Data and sample}

The sample consists of all firms listed on the TSE from 2008 to 2017. We collect financial statement data from the annual reports of the companies listed on the Tehran Stock Exchange and Rahavard-e-Novin database ${ }^{1}$. The annual reports of the companies in the TSE are available at the Research, Development and Islamic Studies Center ${ }^{2}$ and CODAL ${ }^{3}$. The initial sample includes 3250 firm-year observations. However, when financial firms are excluded due to the different nature of the operations of such firms, the final sample decreases to 1580 firm-year observations for test $\mathrm{H} 1$ and 1371 firm-year observations for test H2. Furthermore, it excludes delisted firms and observations without the necessary data to compute the variables. Table 1 outlines the sample selection procedure.

\footnotetext{
${ }^{1}$ The Rahavard-e-Novin database is the most comprehensive database in the Iranian capital market. The full version of this database contains financial reports and the information on capital market. It further provides various options for essential technical analysis (Hesarzadeh \& Bazrafshan, 2018).

${ }^{2}$ www.RDIS.ir/CompaniesReports.asp

${ }^{3}$ www.Codal.ir
} 
Table 1

Sample selection

Panel A

Total Sample

All firms listed on the Tehran Stock Exchange from 2008 to 2017

3250

Less: firm-year observations in financial services industries

Less: delisted firms

Less: observations with missing values on financial information or

other control variables used in the present study

Subtotal: number of observations with available data

Less: observations with no CEO experience data

Observations in final analysis for test $\mathrm{H} 1$

Less: observations with no CEO financial expertise data

Observations in final analysis for test $\mathrm{H} 2$

Panel B

\begin{tabular}{lccc} 
Year & N Restatement & N Insider CEO & N Financial expert CEO \\
\hline 2008 & 104 & 41 & 25 \\
2009 & 111 & 43 & 29 \\
2010 & 105 & 47 & 33 \\
2011 & 102 & 54 & 38 \\
2012 & 102 & 53 & 41 \\
2013 & 116 & 60 & 44 \\
2014 & 103 & 62 & 36 \\
2015 & 108 & 63 & 39 \\
2016 & 98 & 65 & 37 \\
2017 & 92 & 63 & 44 \\
Total & 1041 & 551 & 366
\end{tabular}

\subsection{Model specification}

We estimate the following logistic regression models. Model (1) tests the effect of CEO experience on the incidence of FR (H1) and Model (2) examines the effect of CEOs with financial expertise on the incidence of FR (H2).

$$
\begin{aligned}
& \text { Restate }_{i t}=\beta_{0}+\beta_{1} \text { CEOExper }{ }_{i t}+\beta_{2} \text { CEOtenure }_{i t}+\beta_{3} \text { CEOchair }_{i t} \\
& +\beta_{4} \text { CEOown }_{i t}+\beta_{5} B-\text { Size }_{i t}+\beta_{6} B-\text { Ind }_{i t} \\
& +\beta_{7} \text { Conown }_{i t}+\beta_{8} \text { Instown }_{i t}+\beta_{9} \text { Famown }_{i t} \\
& +\beta_{10} \text { Audittype }_{i t}+\beta_{11} \text { Audittenure }_{i t}+\beta_{12} \text { Weak }_{i t} \\
& +\beta_{13} \text { Zscore }_{i t}+\beta_{14} \text { FAge }_{i t}+\beta_{15} \text { Lev }_{i t}+\beta_{16} \text { Finance }_{i t} \\
& +\beta_{17} \text { Size }_{i t}+\beta_{18} \text { Recinv }_{i t}+\beta_{19} \text { Growth }_{i t}+\beta_{20} \text { Twoloss }_{i t} \\
& +\beta_{21} \text { Accrual }_{i t}+\text { Industry Fixed Effect } \\
& + \text { Year Fixed Effect }+\varepsilon_{i t}
\end{aligned}
$$

$$
\begin{aligned}
& \text { Restateit }=\beta_{0}+\beta_{1} \text { CEOFexp }_{i t}+\beta_{2} \text { CEOtenure }_{i t}+\beta_{3} \text { CEOchair }_{i t} \\
& +\beta_{4} \text { CEOown }_{i t}+\beta_{5} B-\text { Size }_{i t}+\beta_{6} B-\text { Ind }_{i t} \\
& +\beta_{7} \text { Conown }_{i t}+\beta_{8} \text { Instown }_{i t}+\beta_{9} \text { Famown }_{i t} \\
& +\beta_{10} \text { Audittype }_{i t}+\beta_{11} \text { Audittenure }_{i t}+\beta_{12} \text { Weak }_{i t} \\
& +\beta_{13} \text { Zscore }_{i t}+\beta_{14} \text { FAge }_{i t}+\beta_{15} \text { Lev }_{i t}+\beta_{16} \text { Finance }_{i t} \\
& +\beta_{17} \text { Size }_{i t}+\beta_{18} \text { Recinv }_{i t}+\beta_{19} \text { Growth }_{i t}+\beta_{20} \text { Twoloss }_{i t} \\
& +\beta_{21} \text { Accrual }_{i t}+\text { Industry Fixed Effect } \\
& + \text { Year Fixed Effect }+\varepsilon_{i t}
\end{aligned}
$$

Where Restate is an indicator variable that equals 1 if the company restated its financial statements and 0 otherwise. Our variables of primary interest are CEOExper and CEOFexp. CEOExper is an indicator variable that equals one if the CEO is hired from inside the firm and 0 otherwise. CEOFexp is an indicator variable that equals 1 if the CEO is qualified for financial expertise and 0 otherwise.

We include several control variables in the regression models. We control for CEO characteristics - CEO tenure (CEOtenure), CEO duality (CEOchair), and CEO ownership (CEOown)
- in our analysis, because these characteristics can affect firm performance and the financial reporting process. Prior studies suggest that CEOtenure is negatively associated with firm performance (e.g., Bizjak et al., 2009; Veprauskaite \& Adams, 2013) and internal control quality (Lin et al., 2014). Moreover, CEO duality (CEOchair) reduces the effectiveness of the board's monitoring function and eliminates an additional monitoring mechanism (Beasley, 1996; Dechow et al., 1995). Abbott et al. (2012) find that there is a positive relationship between CEOchair and FR. In addition, top managers with higher shareholdings have stronger control over the firm, and, hence, more ability to pursue their own private interests (Lin et al., 2014). Lin et al. (2014) show that the CEO ownership (CEOown) decreases internal control quality and increases the financial reporting weakness. We expect a positive relationship between these variables and FR.

Consistent with Beasley (1996), we expect a positive relationship between B-Size and FR. Beasley (1996) also posits that independent directors have reputational capital incentives to minimize the incidence of FR. Thus, we expect a negative association between $B$-Ind and FR. ${ }^{4}$ In addition, differences in the structure of ownership could impact on the FR (e.g., DeFond \& Jiambalvo, 1991; GAO; 2002). DeFond \& Jiambalvo (1991) posit that an increased ownership concentration (Conown) reduces the incidence of FR. Further, Abbott et al. (2004) report that there is a negative relation between block shareholder ownership (Instown) and FR, because of the increased monitoring function by these types of shareholders (Jiang et al., 2015). We expect a negative association between Conown and Instown with FR. Moreover, Wang (2006) shows that there is a negative relationship between family ownership and earnings management, which subsequently reduces the possibility of misstatements and FR. Thus, we expect a negative relation between family ownership (Famown) and FR.

Chin \& Chi (2009) argue that with the enhancement of audit quality, the likelihood of restatement decreases. Therefore, we controlled for auditor type ${ }^{5}$ (Audittype) and audit tenure (Audittenure) variables as they are proxies for audit quality (Lai \& Liu, 2018). We predict a negative association between Audittype and Audittenure with FR. Further, we include the variable of the internal control weakness (Weak) as one of the determining factors in FR (Plumlee \& Yohn, 2010), and predict a positive association between Weak and FR.

Furthermore, financial distress increases the likelihood of opportunistic reporting of the management, and, thus, leads to FR (Jiang et al., 2015). Moreover, firm age is associated with reporting problems; presumably as the firm age increases, the likelihood of FR decreases, owing to the fact that young firms face the problems that lead to more FR (Beasley, 1996). Hence, financial distress (Zscore) and firm age (FAge) are included in the equation. We predict a negative association between Zscore and FAge with FR. Zhang et al. (2018) find that firms with higher leverage are more likely to restate financial statements. Therefore, we expect a positive association between Lev and FR. Further, Presley \& Abbott (2013) show that with an increase in external financing (Finance), the likelihood of FR decreases. We predict a negative association between Finance and FR. We also include firm size

${ }^{4}$ In this study, the important role of the audit committee on the financial restatement is uncontrolled, because the formation of an audit committee is newly (since 2013) enforced for listed firms.

${ }^{5}$ The international big audit firms (BIG4) did not set up their activities in Iran (see Bagherpour et al., 2014b). The Audit Organization of Iran is a government entity that is as acknowledged to be the largest audit firm in Iran. Therefore, we classify audit firms into two groups - big (audit organization) and small (the other audit firms) (Hesarzadeh \& Bazrafshan, 2018). 
(Size), because Ji et al. (2017) find that large firms have less incentive for earnings management, which is associated with a reduced likelihood of FR (Zhang et al., 2018). We expect a negative association between Size and FR.

In addition, we include firm complexity (Recinv) since firm complexity increases the likelihood of audit failure, which, in turn, leads to an increase in the incidence of FR (DeFond \& Zhang, 2014). Thus, we expect a positive relation between Recinv and FR. Moreover, the desire to maintain a firm's rate of growth can create an incentive to manipulate earnings (Beasley, 1996). Abbott et al. (2004) found that there is a positive relation between Growth and FR. We predict a positive association between Growth and FR. Previous studies have shown that weak financial performance provides an incentive to misstate earnings (Scholz, 2008). To control for this, we include consecutive losses (Twoloss). We expect a positive association between Twoloss and FR. Finally, we include the total accruals to sales (Accrual) that could affect the restatement (Zhang et al., 2018). The changes in accruals increase the likelihood of earning manipulation (Schipper \& Vincent, 2003). We expect a positive association between Accrual and FR. We also include industry and year dummy variables in all our regression specifications. Table 2 provides a summary of the variable definitions.

Table 2

Variable definition

\begin{tabular}{|c|c|}
\hline Variable name & Definitions \\
\hline Restate & $\begin{array}{l}\text { An indicator variable which equals } 1 \text { if the company restated } \\
\text { its financial statements and } 0 \text { otherwise. }\end{array}$ \\
\hline CEOExper & $\begin{array}{l}\text { An indicator variable which equals one if CEO is hired from } \\
\text { inside the firm and } 0 \text { otherwise. }\end{array}$ \\
\hline CEOFexp & $\begin{array}{l}\text { An indicator variable which equals } 1 \text { if CEO is qualified for } \\
\text { financial expertise and } 0 \text { otherwise. Defined CEO as a financial } \\
\text { expert if who hold accounting qualification, or have work } \\
\text { experience as auditor, CFO, controller and or other accounting } \\
\text { related positions. }\end{array}$ \\
\hline CEOtenure & The number of years working as a CEO in the firm. \\
\hline CEOchair & $\begin{array}{l}\text { An indicator variable which equals } 1 \text { if the CEO is also the } \\
\text { chairman (or vice chairman) of the board, } 0 \text { otherwise. }\end{array}$ \\
\hline CEOown & The percentage of shares owned by the CEO. \\
\hline B-Size & The number of directors on the board. \\
\hline B-Ind & $\begin{array}{l}\text { The percentage of independent directors on the board of } \\
\text { directors. }\end{array}$ \\
\hline Conown & $\begin{array}{l}\text { The percentage of a firm's outstanding shares that are owned } \\
\text { by the largest shareholder }(=>\% 5) \text {. }\end{array}$ \\
\hline Instown & The percentage of shares held by institutional investors \\
\hline Famown & $\begin{array}{l}\text { An indicator variable which equals } 1 \text { if the firm is classified as } \\
\text { a family firm, } 0 \text { otherwise. }\end{array}$ \\
\hline Audittype & $\begin{array}{l}\text { An indicator variable which equals } 1 \text { if the auditor is a big } \\
\text { audit firm and } 0 \text { otherwise. }\end{array}$ \\
\hline Audittenure & $\begin{array}{l}\text { The number of years that an auditor has been retained by the } \\
\text { firm. }\end{array}$ \\
\hline Weak & $\begin{array}{l}\text { An indicator variable which equals } 1 \text { if there is a material } \\
\text { weakness in internal control, } 0 \text { otherwise. }\end{array}$ \\
\hline Zscore & $\begin{array}{l}\text { Financial distress calculated using a modified Altman's } \\
\text { proposed by MacKie-Mason (1990). The higher Zscore show } \\
\text { that lower the chance of financial distress. The MacKie-Mason } \\
\text { (1990) model is as follows: } \\
\mathrm{Z}=3.3 \text { (EBIT/TA) }+1 \text { (Sales/TA) }+1.4 \text { (Retained } \\
\text { Earnings/TA) + } 1.2 \text { (Working Capital/TA). }\end{array}$ \\
\hline FAge & $\begin{array}{l}\text { The natural logarithm of the number of years since the } \\
\text { company was established. }\end{array}$ \\
\hline Lev & The ratio of total debt to total assets. \\
\hline Finance & $\begin{array}{l}\text { Operating cash flows minus average capital expenditures (it-3 } \\
\text { to it-1), divided by lagged current assets. }\end{array}$ \\
\hline Size & The natural logarithm of total assets. \\
\hline Recinv & The ratio of receivables and inventories to total assets. \\
\hline Growth & The percentage of change in annual sales revenue. \\
\hline Twoloss & $\begin{array}{l}\text { An indicator variable which equals } 1 \text { if a client reports loss for } \\
\text { two consecutive years. }\end{array}$ \\
\hline Accrual & $\begin{array}{l}\text { Net income minus operating cash flows and divided by lagged } \\
\text { assets. }\end{array}$ \\
\hline
\end{tabular}

\section{Empirical results}

\subsection{Descriptive statistics and correlations}

The descriptive statistics of the research variables are shown in Panels A and B of Table 3. Panel A presents the descriptive statistics of all the variables. All continuous variables are winsorized at the top and bottom $1 \%$ of their distributions. Panel A of Table 3 shows that the mean of Restate is $68 \%$, which is notably higher than the mean of restatements in other countries, such as the USA (9\%; Blankley et al, 2012) and China (16\%; Zhang et al., 2018). In addition, Panel A of Table 2 reveals that $35 \%$ companies in the research sample used insider CEOs (CEOExper). This is considerably different from the mean insider CEOs of 69\% for firms in the S\&P 1500 (Brockman et al., 2019). Firms in the S\&P 1500 are large; they are also likely to be more complex, in which CEO inhouse experience is likely to be more important (Brockman et al., 2019). Moreover, Panel A of Table 3 indicates that $27 \%$ of CEOs in the research sample have financial expertise. This is consistent with the mean CEOFexp of $28 \%$ obtained for the Iranian listed firms at the international level (Salehi et al., 2018). In contrast, this percentage is different from that of Custodio \& Metzger (2014) in S\&P 1500 firms (41\%).

The average CEO duality (CEOchair) is $21 \%$, which is notably lower than the mean of CEO duality in other countries, such as the USA (45\%; Gounopoulos \& Pham, 2018). The mean CEO tenure is 3.6 years and the average CEO ownership is $16 \%$, which differs from the research carried out by Gounopoulos \& Pham (2018) in US. listed firms (4.98; $11 \%$ respectively). The average ownership concentration is $77 \%$, which demonstrates a high level of ownership concentration in Iranian listed companies (Mashayekhi \& Mashayekh, 2008). The mean of leverage (Lev) is 61\%, which is consistent with Moayedi \& Aminfard (2012), who note that the finance system in Iran is dominated by creditors.

Panel B of Table 3 reports the Spearman rank correlation matrix for the main variables. The correlation between CEOExper and Reatate is negative $(-0.001)$ and not significant, indicating that insider CEOs may not be associated with financial restatement. In addition, the correlation between CEOFexp and Reatate is negative (-0.458) and statistically significant, indicating that CEO financial expertise may be associated with financial restatement. The correlations between the other variables (in two models) never exceed 50 percent, thus alleviating the concerns about multicollinearity affecting the results. Furthermore, the VIF scores (when estimated regressions) in all models are below the acceptable threshold of 10 (Field, 2013), thereby suggesting that multicollinearity is not a significant issue.

\subsection{Multivariate analysis}

Table 4 presents the results of the multivariate analyses for the research models. The results show that the coefficient on CEOExper is 0.337, which is significantly (P-value $=$ 0.015 ) positively associated with the incidence of FR. Therefore, CEOs with more in-house experience increase the likelihood of the incidence of FR, and, hence, our first hypothesis (H1) that insider CEOs can be associated with the incidence of FR is supported. Such findings are consistent with the continuity perspective (Lauterbach et al., 1999) and support the resource dependence (Pfeffer \& Salancik, 1978) and upper echelons (Hambrick \& Mason, 1984) perspectives, which give emphasis to the advantages of recruiting outside CEOs. Furthermore, consistent with the second hypothesis (H2), 
Table 3

Descriptive Statistics and correlations

\begin{tabular}{|c|c|c|c|c|c|c|}
\hline \multicolumn{7}{|c|}{ Panel A. Descriptive statistics of variable } \\
\hline Variable & $\mathrm{N}$ & Mean & Median & STD & Min. & Max. \\
\hline Restate & 1580 & 0.685 & 1.000 & 0.474 & 0.000 & 1.000 \\
\hline CEOExper & 1580 & 0.348 & 0.000 & 0.476 & 0.000 & 1.000 \\
\hline CEOFexp & 1371 & 0.266 & 0.000 & 0.442 & 0.000 & 1.000 \\
\hline CEOtenure & 1580 & 3.563 & 3.000 & 2.668 & 1.000 & 13.000 \\
\hline CEOchair & 1580 & 0.216 & 0.000 & 0.411 & 0.000 & 1.000 \\
\hline CEOown & 1580 & 0.161 & 0.000 & 0.261 & 0.000 & 0.458 \\
\hline B-Size & 1580 & 5.110 & 5.000 & 0.423 & 5.000 & 7.000 \\
\hline B-Ind & 1580 & 0.647 & 0.600 & 0.177 & 0.200 & 1.000 \\
\hline Conown & 1580 & 0.770 & 0.823 & 0.181 & 0.096 & 0.983 \\
\hline isto & 1580 & 0.377 & 0.299 & 0.3 & 0.000 & 0.972 \\
\hline Famown & 1580 & 0.120 & 0.000 & 0.325 & 0.000 & 1.000 \\
\hline udi & 1580 & 0.228 & 0.000 & 0.4 & 0.000 & 1.000 \\
\hline udittenu & 1580 & 3.728 & 3.000 & 2.6 & 1.000 & 14.000 \\
\hline Weak & 1580 & 0.464 & 0.000 & 0.498 & 0.000 & 1.000 \\
\hline Zscore & 1580 & 1.873 & 1.829 & 1.246 & -2.094 & 6.936 \\
\hline FAge & 1580 & 3.335 & 3.663 & 0.418 & 2.302 & 4.413 \\
\hline Lev & 1580 & 0.612 & 0.627 & 0.204 & 0.173 & 1.228 \\
\hline Finance & 1580 & 0.344 & 0.242 & 0.385 & -0.236 & 2.166 \\
\hline Size & 1580 & 13.778 & 13.634 & 1.396 & 10.676 & 18.381 \\
\hline Recinv & 1580 & 0.513 & 0.537 & 0.200 & 0.063 & 0.895 \\
\hline Growth & 1580 & 0.206 & 0.142 & 0.487 & -0.739 & 4.561 \\
\hline Twoloss & 1580 & 0.051 & 0.000 & 0.201 & 0.000 & 1.000 \\
\hline Accrual & 1580 & -0.018 & -0.026 & 0.130 & -0.468 & 0.311 \\
\hline \multicolumn{7}{|c|}{ Panel C. Spearman rank correlation matrix for main variables } \\
\hline \multicolumn{2}{|l|}{ Variable } & \multicolumn{2}{|c|}{ Restate } & \multicolumn{3}{|c|}{$\mathrm{N}$} \\
\hline \multicolumn{2}{|l|}{ CEOExper } & \multirow{2}{*}{\multicolumn{2}{|c|}{$\begin{array}{l}-0.001 \\
-0.458 * * *\end{array}$}} & \multicolumn{3}{|c|}{1580} \\
\hline \multicolumn{2}{|l|}{ CEOFexp } & & & & \multicolumn{2}{|l|}{1371} \\
\hline
\end{tabular}

All variables are defined in Appendix A. ${ }^{*},{ }^{* *}$, and ${ }^{* * *}$ denote statistical significance at the $10 \%, 5 \%$, and $1 \%$ level, respectively.

CEOFexp is negatively associated (Coeff $=-2.125$, P-value $=$ 0.000) with the incidence of FR. This result shows that with an increase in CEO financial expertise, the likelihood of the incidence of FR decreases, which is consistent with the previous research about the benefits of financial expert CEOs in financial reporting (e.g., Jiang et al., 2013; Custodio \& Metzger, 2014; Kalelkar \& Khan, 2016).

Commenting on the control variables, Table 4 reveals that CEOs with higher tenure (CEOtenure) increase the incidence of FR, which is consistent with prior studies (e.g., Bizjak et al., 2009; Lin et al., 2014). The association between institutional ownership (Instown) and family ownership (Famown) and the incidence of FR is negative and significant, which is consistent with prior studies (Abbott et al., 2004; Wang, 2006). Furthermore, consistent with prior literature, internal controls weakness (Weak) has a significant positive association (Plumlee \& Yohn, 2010) and the firm age (FAge) has a significant negative association with the incidence of FR (Beasley, 1996). In addition, the result shows that contrary to our expectations Lev is negative and Size is positively associated with the incidence of FR. Table 4 also reveals that client firms with consecutive losses (Twoloss) are more likely to restate their FR, which is consistent with prior literature (DeFond \& Zhang, 2014; Scholz, 2008). The explanatory power of the variables in Model (1) is approximately $13 \%$ and in Model (2) it is approximately $24 \%$, which is comparable with prior studies (e.g., Presley \& Abbott, 2013; Zhang et al., 2018).
Table 4

Regressions of CEO experience and financial expertise on financial restatement

\begin{tabular}{|c|c|c|c|c|c|}
\hline \multirow{2}{*}{$\begin{array}{l}\text { Model } \\
\text { Variable }\end{array}$} & \multirow[b]{2}{*}{$\begin{array}{l}\text { Expected } \\
\text { sign }\end{array}$} & \multicolumn{2}{|c|}{ Model 1 (H1) } & \multicolumn{2}{|c|}{ Model 2 (H2) } \\
\hline & & Coefficient & P-value & Coefficient & P-value \\
\hline Intercept & & $-2.756^{*}$ & 0.069 & -2.643 & 0.110 \\
\hline CEOExper & $?$ & $0.333 * *$ & 0.015 & & \\
\hline CEOFexp & - & & & $-2.125 * * *$ & 0.000 \\
\hline CEOtenure & + & $0.052 * *$ & 0.031 & $0.054 *$ & 0.051 \\
\hline CEOchair & + & 0.132 & 0.404 & 0.158 & 0.386 \\
\hline CEOown & + & 0.044 & 0.856 & 0.031 & 0.913 \\
\hline B-Size & + & 0.192 & 0.255 & 0.090 & 0.638 \\
\hline B-Ind & - & -0.468 & 0.237 & -0.438 & 0.346 \\
\hline Conown & - & 0.513 & 0.174 & 0.008 & 0.985 \\
\hline Instown & - & $-0.573 * * *$ & 0.005 & $-0.977 * * *$ & 0.000 \\
\hline Famown & - & $-0.443 * *$ & 0.023 & -0.233 & 0.351 \\
\hline Audittype & - & 0.078 & 0.658 & -0.036 & 0.859 \\
\hline Audittenure & - & -0.012 & 0.636 & -0.039 & 0.193 \\
\hline Weak & + & $1.091 * * *$ & 0.000 & $0.584 * * *$ & 0.000 \\
\hline Zscore & - & -0.029 & 0.695 & 0.019 & 0.833 \\
\hline FAge & - & $-0.502 * * *$ & 0.002 & -0.148 & 0.448 \\
\hline Lev & + & $-0.796 * *$ & 0.074 & -0.749 & 0.162 \\
\hline Finance & - & 0.368 & 0.126 & -0.159 & 0.565 \\
\hline Size & - & $0.194 * * *$ & 0.000 & $0.224 * * *$ & 0.000 \\
\hline Recinv & + & 0.645 & 0.138 & 0.835 & 0.114 \\
\hline Growth & + & -0.103 & 0.446 & -0.171 & 0.306 \\
\hline Twoloss & + & $0.724 * *$ & 0.033 & 0.631 & 0.150 \\
\hline Accrual & + & -0.434 & 0.477 & $-1.311^{*}$ & 0.067 \\
\hline \multicolumn{2}{|c|}{ Industry Fixed Effect } & \multicolumn{2}{|c|}{ Included } & \multicolumn{2}{|c|}{ Included } \\
\hline \multicolumn{2}{|c|}{ Year Fixed Effect } & \multicolumn{2}{|c|}{ Included } & \multicolumn{2}{|c|}{ Included } \\
\hline \multicolumn{2}{|c|}{ Observations } & \multicolumn{2}{|c|}{1580} & \multicolumn{2}{|c|}{1371} \\
\hline \multicolumn{2}{|l|}{ LR [prob] } & \multicolumn{2}{|c|}{$263.39 * * *[0.000]$} & \multicolumn{2}{|c|}{$441.21 * * *[0.000]$} \\
\hline \multicolumn{2}{|l|}{ Pseudo $\mathrm{R}^{2}$} & \multicolumn{2}{|c|}{0.1299} & \multicolumn{2}{|c|}{0.2451} \\
\hline
\end{tabular}

This table illustrates the effect of CEO experience and financial expertise on financial restatement. All variables are defined in Appendix A. * ${ }^{* *}$, and ${ }^{* * *}$ denote statistical significance at the $10 \%, 5 \%$, and $1 \%$ level, respectively.

\subsection{Supplementary analysis}

\subsubsection{Interaction effects between CEO experience and CEO financial expertise}

The main results indicate that CEO experience and CEO financial expertise are associated with the increase and decrease in FR, respectively. Such findings raise the question concerning how the interaction of these two CEO characteristics affects the incidence of financial restatements. To examine this question, CEOExper is allowed to interact with CEOFexp, and this interaction term is included in the model. Table 5 reveals that the coefficient of CEOExper* CEOpower is significant and negative (P-value $=0.030$ ), suggesting that a CEO with the combined attributes of experience and financial expertise leads to high-quality financial reporting.

In addition, the preceding findings are supplemented by performing a subsample analysis. In the first step, the sample is separated into the financial expert CEO (CEOFexp) group and non-financial expert CEO (NonCEOFexp) group in which the observations with financial expert CEO are considered as the CEOFexp group and others as the NonCEOFexp group. As reported in Table 5, CEOExper is negatively but insignificantly associated with FR for the CEOFexp group (P-value = 0.069), and CEOExper is positively and significantly associated with FR for the NonCEOFexp group (P-value $=0.023$ ). In the next step, the sample is separated into the CEO with 
more in-house experience (CEOExper) group and CEO with less in-house experience (NonCEOExper) group in which the observations with CEO with experience are considered as the CEOExper group and others as the NonCEOExper group. The results in Table 5 show that CEOFexp is negatively significantly associated with FR for both groups. However, the level of significance and size effect of CEOFexp on the FR for the CEOExper group is significantly higher than for the NonCEOExper group. Overall, the results highlight the importance of financial expertise and show that the effect of CEO experience on financial reporting is more observable if they qualify as a financial expert.

\subsubsection{CEO power}

Previous studies reveal that CEOs with more decisionmaking power can greatly impact the financial strategies of the company (e.g., Chikh \& Filbien, 2011; Veprauskait \& Adams, 2013; Gounopoulos \& Pham, 2018). In particular, Gounopoulos \& Pham (2018) find that the effect of financial expert CEOs on the reduction in accrual earnings management is more profound when they exercise more power and the decision-making power of CEOs enables them to influence CFOs' decisions more strongly. Therefore, it can be expected that the association between CEO characteristics and financial restatements are also be affected by CEO power.

While no measure is likely to capture every possible dimension of CEO power (Veprauskait \& Adams, 2013), we construct CEO power by four sources of power - CEO tenure, CEO duality, CEO ownership, and board power - as supported in the extant literature (e.g., see Combs et al., 2007; Liu \& Jiraporn, 2010; Veprauskait \& Adams, 2013; Sheikh, 2018, 2019).

CEO power is enhanced with the length of tenure, by reason of being able to affect the selection of the board members and control the board composition (Hermalin \& Weisbach, 1998). Long-standing CEOs, compared to CEOs with short tenure, are more likely to enhance their expertise and experience regarding the corporate operations, and this can affect the way they make and implement their decisions (Herrmann \& Datta, 2002). Accordingly, tenure could be used as a proxy for expert power (Gounopoulos \& Pham, 2018). CEO duality is one of the other ways of enhancing power in which the CEO also holds the position of the chairman of the board (Hermalin \& Weisbach, 1998). CEO duality is used as a proxy for positional power (Gounopoulos \& Pham, 2018); since CEOs hold the highest position in the corporate hierarchy, they exert a dominant influence, which enhances their decision-making power (Larcker \& Tayan, 2012). Moreover, CEOs who have a major ownership, take advantage of more power in the company compared to CEOs without stock ownership (ownership power) (Larcker \& Tayan, 2012; Veprauskait \& Adams, 2013). Finally, outsider or independent directors on the board are more effective in monitoring CEOs (Bhagat \& Black, 2002; Fama \& Jensen, 1983). A high proportion of outsider directors restricts CEO opportunities to make unilateral decisions (Sheikh, 2018). Thus, board independence could be regarded as a proxy for the board power (Sheikh, 2018).

We standardize and aggregate the four variables to generate the variable CEO power. That is, CEO tenure equals 1 if the tenure length is greater than the sample median, otherwise 0 (Sheikh, 2018). CEO duality is defined as a dummy variable and equals 1 if the CEO also holds the chairman position of the board, otherwise 0. Moreover, CEO ownership equals 1 if $\mathrm{CEO}$ is a majority shareholder (i.e., ownership
Table 5

Analysis of the interaction effect between CEO experience and CEO financial expertise

\begin{tabular}{|c|c|c|c|c|c|}
\hline \multirow[b]{2}{*}{ Variable } & \multirow{2}{*}{$\begin{array}{c}\text { Restate } \\
\text { Coefficient } \\
\text { [P-value] }\end{array}$} & \multicolumn{2}{|c|}{ Restate } & \multicolumn{2}{|r|}{ Restate } \\
\hline & & $\begin{array}{c}\text { CEOFexp } \\
\text { Coefficient } \\
\text { [P-value] }\end{array}$ & $\begin{array}{c}\text { NonCEOFexp } \\
\text { Coefficient } \\
\text { [P-value] }\end{array}$ & $\begin{array}{c}\text { CEOExper } \\
\text { Coefficient } \\
\text { [P-value }]\end{array}$ & $\begin{array}{c}\text { NonCEOExper } \\
\text { Coefficient } \\
\text { [P-value] }\end{array}$ \\
\hline Intercept & $\begin{array}{l}-2.393 \\
{[0.153]}\end{array}$ & $\begin{array}{l}-7.953 \\
{[0.106]}\end{array}$ & $\begin{array}{c}-2.313 \\
{[0.200]}\end{array}$ & $\begin{array}{c}-1.803 \\
{[0.613]}\end{array}$ & $\begin{array}{c}-4.411 * \\
{[0.065]}\end{array}$ \\
\hline CEOExper & $\begin{array}{c}0.287 \\
{[0.123]}\end{array}$ & $\begin{array}{c}-0.735^{*} \\
{[0.069]}\end{array}$ & $\begin{array}{l}0.398 * * \\
{[0.023]}\end{array}$ & & \\
\hline CEOFexp & $\begin{array}{c}-1.864 * * * \\
{[0.000]}\end{array}$ & & & $\begin{array}{c}-3.307^{* * * *} \\
{[0.000]}\end{array}$ & $\begin{array}{c}-2.050 * * * \\
{[0.000]}\end{array}$ \\
\hline $\begin{array}{l}\text { CEOExper* } \\
\text { CEOFexp }\end{array}$ & $\begin{array}{c}-0.759 * * \\
{[0.030]}\end{array}$ & & & & \\
\hline CEOtenure & $\begin{array}{l}0.059 * * \\
{[0.036]}\end{array}$ & $\begin{array}{c}0.103 \\
{[0.153]}\end{array}$ & $\begin{array}{l}0.062 * * \\
{[0.039]}\end{array}$ & $\begin{array}{c}0.029 \\
{[0.599]}\end{array}$ & $\begin{array}{c}0.116 * * * \\
{[0.005]}\end{array}$ \\
\hline CEOchair & $\begin{array}{c}0.175 \\
{[0.346]}\end{array}$ & $\begin{array}{c}-1.120 * * \\
{[0.013]}\end{array}$ & $\begin{array}{c}0.563^{* * * *} \\
{[0.009]}\end{array}$ & $\begin{array}{c}0.282 \\
{[0.458]}\end{array}$ & $\begin{array}{c}-0.084 \\
{[0.727]}\end{array}$ \\
\hline CEOown & $\begin{array}{l}-0.059 \\
{[0.838]}\end{array}$ & $\begin{array}{l}-0.142 \\
{[0.836]}\end{array}$ & $\begin{array}{c}0.038 \\
{[0.902]}\end{array}$ & $\begin{array}{c}-1.213 * \\
{[0.078]}\end{array}$ & $\begin{array}{c}0.132 \\
{[0.702]}\end{array}$ \\
\hline B-Size & $\begin{array}{c}0.046 \\
{[0.804]}\end{array}$ & $\begin{array}{c}1.046 \\
{[0.131]}\end{array}$ & $\begin{array}{l}-0.092 \\
{[0.641]}\end{array}$ & $\begin{array}{c}-0.675^{*} \\
{[0.063]}\end{array}$ & $\begin{array}{c}0.088 \\
{[0.782]}\end{array}$ \\
\hline B-Ind & $\begin{array}{l}-0.465 \\
{[0.322]}\end{array}$ & $\begin{array}{l}-0.756 \\
{[0.498]}\end{array}$ & $\begin{array}{l}-0.604 \\
{[0.227]}\end{array}$ & $\begin{array}{l}-0.006 \\
{[0.994]}\end{array}$ & $\begin{array}{c}0.057 \\
{[0.926]}\end{array}$ \\
\hline Conown & $\begin{array}{l}-0.108 \\
{[0.808]}\end{array}$ & $\begin{array}{l}2.909 * * \\
{[0.011]}\end{array}$ & $\begin{array}{l}-0.094 \\
{[0.860]}\end{array}$ & $\begin{array}{c}0.213 \\
{[0.828]}\end{array}$ & $\begin{array}{c}0.329 \\
{[0.630]}\end{array}$ \\
\hline Instown & $\begin{array}{c}-0.959 * * * \\
{[0.000]}\end{array}$ & $\begin{array}{c}-2.480 * * * \\
{[0.000]}\end{array}$ & $\begin{array}{l}-0.416 \\
{[0.105]}\end{array}$ & $\begin{array}{c}-0.347 \\
{[0.520]}\end{array}$ & $\begin{array}{c}-1.096^{* * *} \\
{[0.000]}\end{array}$ \\
\hline Famown & $\begin{array}{c}-0.294 \\
{[0.210]}\end{array}$ & $\begin{array}{c}0.458 \\
{[0.435]}\end{array}$ & $\begin{array}{c}-0.288 \\
{[0.270]}\end{array}$ & $\begin{array}{c}-0.728^{*} \\
{[0.089]}\end{array}$ & $\begin{array}{c}0.118 \\
{[0.755]}\end{array}$ \\
\hline Audittype & $\begin{array}{l}-0.032 \\
{[0.877]}\end{array}$ & $\begin{array}{c}0.141 \\
{[0.799]}\end{array}$ & $\begin{array}{c}0.207 \\
{[0.350]}\end{array}$ & $\begin{array}{l}-0.489 \\
{[0.338]}\end{array}$ & $\begin{array}{c}0.103 \\
{[0.667]}\end{array}$ \\
\hline Audittenure & $\begin{array}{l}-0.041 \\
{[0.179]}\end{array}$ & $\begin{array}{c}0.062 \\
{[0.429]}\end{array}$ & $\begin{array}{c}-0.072 * * \\
{[0.026]}\end{array}$ & $\begin{array}{c}0.021 \\
{[0.755]}\end{array}$ & $\begin{array}{c}-0.063^{*} \\
{[0.092]}\end{array}$ \\
\hline Weak & $\begin{array}{c}0.578^{* * * *} \\
{[0.000]}\end{array}$ & $\begin{array}{l}-0.127 \\
{[0.741]}\end{array}$ & $\begin{array}{c}0.706^{* * * *} \\
{[0.000]}\end{array}$ & $\begin{array}{l}-0.214 \\
{[0.502]}\end{array}$ & $\begin{array}{c}0.682^{* * * *} \\
{[0.000]}\end{array}$ \\
\hline Zscore & $\begin{array}{c}0.028 \\
{[0.756]}\end{array}$ & $\begin{array}{c}-0.090 \\
{[0.660]}\end{array}$ & $\begin{array}{c}0.045 \\
{[0.649]}\end{array}$ & $\begin{array}{c}-0.548^{* *} \\
{[0.011]}\end{array}$ & $\begin{array}{c}0.184 \\
{[0.102]}\end{array}$ \\
\hline FAge & $\begin{array}{l}-0.203 \\
{[0.303]}\end{array}$ & $\begin{array}{c}-0.940 * \\
{[0.096]}\end{array}$ & $\begin{array}{l}-0.063 \\
{[0.746]}\end{array}$ & $\begin{array}{c}0.458 \\
{[0.368]}\end{array}$ & $\begin{array}{c}0.155 \\
{[0.509]}\end{array}$ \\
\hline Lev & $\begin{array}{l}-0.634 \\
{[0.242]}\end{array}$ & $\begin{array}{l}-1.210 \\
{[0.311]}\end{array}$ & $\begin{array}{l}-0.490 \\
{[0.402]}\end{array}$ & $\begin{array}{c}-1.944 * * \\
{[0.070]}\end{array}$ & $\begin{array}{c}0.673 \\
{[0.367]}\end{array}$ \\
\hline Finance & $\begin{array}{l}-0.128 \\
{[0.644]}\end{array}$ & $\begin{array}{l}-1.021 \\
{[0.211]}\end{array}$ & $\begin{array}{l}-0.062 \\
{[0.822]}\end{array}$ & $\begin{array}{c}0.394 \\
{[0.548]}\end{array}$ & $\begin{array}{c}-0.086 \\
{[0.796]}\end{array}$ \\
\hline Size & $\begin{array}{c}0.228^{* * * *} \\
{[0.001]}\end{array}$ & $\begin{array}{c}0.082 \\
{[0.578]}\end{array}$ & $\begin{array}{c}0.271 * * * \\
{[0.000]}\end{array}$ & $\begin{array}{l}0.329 * * \\
{[0.036]}\end{array}$ & $\begin{array}{c}0.243 * * * \\
{[0.004]}\end{array}$ \\
\hline Recinv & $\begin{array}{c}0.730 \\
{[0.171]}\end{array}$ & $\begin{array}{c}1.475 \\
{[0.194]}\end{array}$ & $\begin{array}{c}0.176 \\
{[0.856]}\end{array}$ & $\begin{array}{l}3.031 \% * \\
{[0.012]}\end{array}$ & $\begin{array}{c}0.083 \\
{[0.902]}\end{array}$ \\
\hline Growth & $\begin{array}{l}-0.184 \\
{[0.273]}\end{array}$ & $\begin{array}{l}-0.394 \\
{[0.429]}\end{array}$ & $\begin{array}{l}-0.176 \\
{[0.257]}\end{array}$ & $\begin{array}{c}-0.141 \\
{[0.647]}\end{array}$ & $\begin{array}{l}-0.180 \\
{[0.446]}\end{array}$ \\
\hline Twoloss & $\begin{array}{c}0.672 \\
{[0.129]}\end{array}$ & $\begin{array}{c}0.124 \\
{[0.892]}\end{array}$ & $\begin{array}{c}0.627 \\
{[0.121]}\end{array}$ & $\begin{array}{c}0.152 \\
{[0.880]}\end{array}$ & $\begin{array}{l}1.020 * \\
{[0.088]}\end{array}$ \\
\hline Accrual & $\begin{array}{c}-1.245 * \\
{[0.083]}\end{array}$ & $\begin{array}{c}-2.138 \\
{[0.236]}\end{array}$ & $\begin{array}{c}-1.375^{*} \\
{[0.076]}\end{array}$ & $\begin{array}{l}-0.550 \\
{[0.723]}\end{array}$ & $\begin{array}{c}-0.755 \\
{[0.404]}\end{array}$ \\
\hline $\begin{array}{l}\text { Industry Fixed } \\
\text { Effect }\end{array}$ & Included & Included & Included & Included & Included \\
\hline $\begin{array}{l}\text { Year Fixed } \\
\text { Effect }\end{array}$ & Included & Included & Included & Included & Included \\
\hline Observations & 1371 & 366 & 1214 & 485 & 879 \\
\hline LR[prob] & $\begin{array}{c}446.31 * * * \\
{[0.000]}\end{array}$ & $\begin{array}{c}120.18^{* * *} \\
{[0.000]}\end{array}$ & $\begin{array}{c}114.34 * * * \\
{[0.000]}\end{array}$ & $\begin{array}{c}285.22 * * * \\
{[0.000]}\end{array}$ & $\begin{array}{c}264.55^{* * *} \\
{[0.000]}\end{array}$ \\
\hline Pseudo $\mathrm{R}^{2}$ & 0.2479 & 0.2826 & 0.0887 & 0.4451 & 0.2295 \\
\hline
\end{tabular}

This table illustrates interaction effect between CEO experience and CEO financial expertise on financial restatement. All variables are defined in Appendix A. **** and ${ }^{* * *}$ denote statistical significance at the $10 \%, 5 \%$, and $1 \%$ level, respectively.

of more than 3 percent of the total share), and otherwise 0 (Veprauskait \& Adams, 2013). We also create an indicator variable board power that equals 1 if the proportion of independent directors on the board is less than the sample median proportion of independent directors and 0 otherwise (Sheikh, 2018). Finally, the assigned scores to the four variables are summed and CEO power is obtained. 
We then create an interaction term between CEO characteristics (i.e., experience and financial expertise) and CEO power, and run the main regressions (Eq. (1) and Eq. (2)) including the interaction effect. The results are presented in Table 6. The interaction coefficient of CEO experience and CEO power (CEOExper*CEOpower) effect is negative and significant. This shows that CEO power significantly reduces the positive effect of CEO experience on the FR. In other words, insider CEOs who have decision-making power could improve the financial reporting quality by reducing FR. Furthermore, the interaction effect coefficient of CEO financial expertise and CEO power (CEOExper $\left.{ }^{*} C E O p o w e r\right)$ is negative and significant, but its intensity is lower than that of the coefficient of CEOFexp $(\mathrm{P}=0.000)$. That is, the more powerful the financial expert CEOs, the less effect they have on financial reporting.

Table 6

Analysis of the interaction effects of CEO power

\begin{tabular}{|c|c|c|c|c|c|}
\hline \multirow{2}{*}{$\begin{array}{l}\text { Model } \\
\text { Variable }\end{array}$} & \multirow[b]{2}{*}{$\begin{array}{l}\text { Expected } \\
\text { sign }\end{array}$} & \multicolumn{2}{|c|}{ Model 1} & \multicolumn{2}{|c|}{ Model 2} \\
\hline & & Coefficient & P-value & Coefficient & P-value \\
\hline Intercept & & $-2.908 * *$ & 0.036 & $-2.898^{*}$ & 0.073 \\
\hline CEOExper & ? & $0.725 * * *$ & 0.001 & & \\
\hline CEOExper* CEOpower & ? & $-0.323 * *$ & 0.031 & & \\
\hline CEOFexp & - & & & $-1.650 * * *$ & 0.000 \\
\hline CEOFexp* CEOpower & ? & & & $-0.446^{* *}$ & 0.015 \\
\hline CEOpower & + & $0.238 * * *$ & 0.009 & $0.256 * *$ & 0.014 \\
\hline B-Size & + & 0.192 & 0.254 & 0.082 & 0.666 \\
\hline Conown & - & 0.462 & 0.214 & -0.108 & 0.799 \\
\hline Instown & - & $-0.535 * *$ & 0.008 & $-0.931 * * *$ & 0.000 \\
\hline Famown & - & $-0.393 * *$ & 0.039 & -0.118 & 0.596 \\
\hline Audittype & - & 0.072 & 0.684 & -0.106 & 0.605 \\
\hline Audittenure & - & -0.008 & 0.764 & -0.032 & 0.285 \\
\hline Weak & + & $1.100 * * *$ & 0.000 & $0.575^{* * *}$ & 0.000 \\
\hline Zscore & - & -0.015 & 0.830 & -0.006 & 0.943 \\
\hline FAge & - & $-0.503^{* * *}$ & 0.002 & -0.135 & 0.486 \\
\hline Lev & + & $-0.741^{*}$ & 0.090 & -0.832 & 0.112 \\
\hline Finance & - & 0.387 & 0.107 & -0.127 & 0.645 \\
\hline Size & - & $0.186 * * *$ & 0.001 & $0.224 * * *$ & 0.001 \\
\hline Recinv & + & 0.640 & 0.141 & $0.910^{*}$ & 0.085 \\
\hline Growth & + & -0.091 & 0.498 & -0.173 & 0.294 \\
\hline Twoloss & + & $0.743 * *$ & 0.029 & 0.593 & 0.183 \\
\hline Accrual & + & -0.400 & 0.511 & $-1.299 *$ & 0.089 \\
\hline Industry Fixed Effect & & Includ & & Incluc & led \\
\hline Year Fixed Effect & & Includ & & Incluc & led \\
\hline Observations & & 158 & & 137 & \\
\hline LR (prob) & & $263.16^{* * * *}$ & $(0.000)$ & $442.60 * * *$ & $(0.000)$ \\
\hline Pseudo $\mathrm{R}^{2}$ & & 0.125 & & 0.24 & \\
\hline
\end{tabular}

This table illustrates the effect of CEO experience and financial expertise on financial restatement, controlling for the interaction effect CEO power. CEO power is measured as the sum of the standardized variables: CEO tenure, CEO duality, CEO ownership and board power. All variables are defined in Appendix A. * ,**, and *** denote statistical significance at the $10 \%, 5 \%$, and $1 \%$ level, respectively.

\section{Conclusions}

The theoretical literature presents different views on the effects of CEOs hired from within the company. Hence, we examine whether insider CEOs are linked to FR incidents. In addition, financial experience provides CEOs with a deep understanding of the accounting and financial issues and enables them to make appropriate accounting decisions. Our findings demonstrate that firms hiring CEOs from within are more subject to FR. In contrast, FR is considerably less in firms with financial expert CEOs. Therefore, the results support the theoretical viewpoints of opponents of recruiting successor CEOs from within. Nonetheless, the existing concerns could decrease through appointing insider financial expert CEOs, because our results show that when insider CEOs have finan- cial expertise they can affect the financial reporting quality positively by reducing FR. Overall, our findings demonstrate that CEO financial background is of great importance in improving financial reporting quality. Moreover, our findings suggest that decision-making power could reduce the positive effect of insider CEOs on the FR. In general, this study extends the literature on CEO characteristics and financial restatements.

This study makes a significant contribution to the CEO succession planning literature by showing that the existing concerns about recruiting a CEO successor could be reduced by considering the other characteristics of CEOs, such as financial expertise. Moreover, some evidence on the relative importance of the interaction between CEO characteristics regarding FR is provided, which has not been reviewed in prior research on financial reporting quality. More specifically, previous studies investigate the association between CEO characteristics including CEO overconfidence (Presley \& Abbott, 2013) and CEO age (Huang et al., 2012), and FR, whereas the current study is the first to document the effect of CEO experience and financial expertise on the incidence of FR. Further, the present paper adds to that research stream that examines the manager fixed effects on variables, such as financial reporting quality (Demerjian et al., 2013) and voluntary disclosures (Bamber et al., 2010). Along the same line, this study highlights the significance of CEO characteristics, in general, and CEO financial expertise, in particular, in the corporate governance setting that is considered relevant in prior restatement research (e.g., Abbott et al., 2004; Carcello et al., 2011; Abbott et al., 2012; Habib \& Hossain, 2013). Finally, this paper contributes to the existing knowledge of the determinants and consequences of FR including financial reporting quality (Palmrose \& Scholz, 2004), the reduced firm value (Palmrose \& Scholz, 2004), higher cost of capital (Bardos \& Mishra, 2014), negative stock price reaction (Wilson, 2008; Chen et al., 2014), higher litigation risk, (Palmrose \& Scholz, 2004; Bardos \& Mishra, 2014), and an increase in CEO/CFO turnover (Hennes et al., 2008).

The findings also have important implications for regulators, the boards of directors and shareholders, specifically in emerging markets by suggesting the importance of financial background for senior executives. These findings should be interpreted with caution because of potential limitations. One limitation is the unavailability of sufficient information due to the lack of public disclosure in Iran. For instance, the information about CEO characteristics, such as age and compensation are not considered due to the resistance of the listed companies on the TSE to disclose such information. Moreover, owing to the absence of requirements, many Iranian companies did not constitute audit committees from 2007 to 2013, which meant we were unable to control for the information related to audit committees. Thus, despite using a reasonably large sample, this study could suffer from an omitted variables problem. Future research can review the research problem and control for such information.

\section{Funding}

This research did not receive any specific grant from funding agencies in the public, commercial or not-for-profit sectors.

\section{Conflict of interests}

The authors declare no conflict of interests. 


\section{References}

Abbott, L. J., Parker, S. \& Presley, T. J. (2012). Female board presence and the likelihood of financial restatement. Accounting Horizons, 26 (4), 607-629. https://doi.org/10. 2308/acch-50249

Abbott, L., Parker, S., \& Peters, G. (2004). Audit committee characteristics and restatements. Auditing: A Journal of Practice \& Theory, 23 (1), 69-87. https://doi.org/10. 2308/aud.2004.23.1.69

Agrawal, A., \& Chadha, S. (2005). Corporate governance and accounting scandals. Journal of Law \& Economics, 48 (2), 371-406. http://dx.doi.org/10.1086/430808

Ahamed, N., \& Tripathi, N. N. (2018). Insider or Outsider CEO: Choosing Wisely in Different Circumstances. Global Tensions in Financial Markets, 34, 205-216.

Aier, J. K., Comprix, J., Gunlock, M. T., \& Lee, D. (2005). The financial expertise of CFOs and accounting restatements. Accounting Horizons, 19 (3), 123-135. https://doi.org/ 10.2308/acch.2005.19.3.123

Akhigbe, A., Kudla, R. J., \& Madura, J. (2005). Why are some corporate earnings restatements more damaging? Applied Financial Economics, 15 (5), 327-336. https:// doi.org/10.1080/0960310042000338722

Ali, A., \& Zhang, W. (2015). CEO tenure and earnings management. Journal of Accounting and Economics, 59 (1), 60-79. https://doi.org/10.1016/j.jacceco.2014.11.004

Almer, E. D., Gramling, A. A., \& Kaplan, S. E. (2008). Impact of post-restatement actions taken by a firm on nonprofessional investors' credibility perceptions. Journal of Business Ethics, 80 (1), 61-76. https://doi.org/10.1007/ s10551-007-9442-0

Baatwah, S, R., Salleh, Z., \& Ahmad, N. (2015). CEO characteristics and audit report timeliness: do CEO tenure and financial expertise matter? Managerial Auditing Journal, 30 (8-9), 998-1022. https://doi.org/10.1108/ MAJ-09-2014-1097

Bagherpour, M., Monroe, G., Shailer, G. (2014). Government and managerial influence on auditor switching under partial privatization. Journal of Accounting and Public Policy, 33 (4), 372-390. https://doi.org/10.1016/j.jaccpubpol. 2014.04.004

Balsmeier, B., \& Buchwald, A. (2014). Who promotes more innovations? Inside versus outside hired CEOs. Industrial and Corporate Change, 24 (5), 1013-1045. https://doi. org/10.1093/icc/dtu020

Bamber, L. S., John, J., \& Wang, I.Y. (2010). What's my style? The influence of top managers on voluntary corporate financial disclosure. The Accounting Review, 85 (4), 11311162. https://www.jstor.org/stable/20744154

Bardos, K. S., \& Mishra, D. (2014). Financial restatements, litigation and implied cost of equity. Applied Financial Economics, 24 (1), 51-71. https://doi.org/10.1080/ 09603107.2013 .864033

Beasley, M. S. (1996). An empirical analysis of the relation between the board of director composition and financial statement fraud. The Accounting Review, 71 (4), 443-465. http://www.jstor.org/stable/248566

Bhagat, S., \& Black, B.S. (2002). The non-correlation between board independence and long term firm performance. Journal of Corporation Law, 27, 231-273.

Bizjak, J. M., Lemmon, M. L., \& Naveen, L. (2009). Does the use of peer groups contribute to higher pay and less efficient compensation? Journal of Financial Economics, 90, 152-168. https://doi.org/10.1016/j.jfineco.2007.08.

\section{7}

Blankley, A. I., Hurtt, D. N., \& MacGregor, J. E. (2012). Abnormal audit fees and restatements. Auditing: A Journal of Practice \& Theory, 31 (1), 79-96. https://doi.org/10. 2308/ajpt-10210

Brockman, P., Campbell, J. L., Lee, H. S., and Salas, J. M. (2019). CEO internal experience and voluntary disclosure quality: Evidence from management forecasts. Journal of Business Finance \& Accounting, 46 (3/4), 420 456. https://doi.org/10.1111/jbfa.12361

Brockman, P., Krishnan, g., Lee, H. S., and Salas, J. M. (2019). Implications of CEO succession origin and inhouse experience for audit pricing. Journal of Accounting, Auditing \& Finance, In Press. https://doi.org/10.1177/ $0148558 X 19832104$

Carcello, J, V., Neal, T, L., Palmrose, Z. V., \& Scholz, S. (2011). CEO Involvement in Selecting Board Members, Audit Committee Effectiveness, and Restatements. Contemporary Accounting Research, 28 (2), 396-430. https: //doi.org/10.1111/j.1911-3846.2010.01052.x

Chen, K. Y., Elder, R J., \& Hung, Sh. (2014). Do postrestatement firms care about financial credibility? Evidence from the pre- and post-SOX eras. Journal of Accounting Public Policy, 33 (2), 107-126. https://doi.org/10. 1016/j.jaccpubpol.2013.12.002

Chikh, S., \& Filbien, J. Y. (2011). Acquisitions and CEO power: Evidence from French networks. Journal of Corporate Finance, 17 (5), 1221-1236. https://doi.org/10. 1016/j.jcorpfin.2011.06.007

Chin, CL., \& Chi, H. Y. (2009). Reducing restatement with Increased Industry Expertise. Contemporary Accounting Research, 26 (3), 729-765. https://doi.org/10.1506/car. 26.3.4

Combs, J. G., Ketchen, D. J., Perryman, A. A., \& Donahue, M. S. (2007). The moderating effects of CEO power on the board composition-firm performance relationship. Journal of Management Studies, 44 (8), 1299-1323. https: //doi.org/10.1111/j.1467-6486.2007.00708.x

Crossland, C., \& Hambrick, D. C. (2007). How national systems differ in their constraints on corporate executives: A study of CEO effects in three countries. Strategic Management Journal, 28 (8), 767-789. https://doi.org/10. $1002 /$ smj. 610

Cullinan, C.P, \& Roush, P. B. (2011). Has the likelihood of appointing a CEO with an accounting/ finance background changed in the post-Sarbanes Oxley era? Research in Accounting Regulation, 23 (1), 71-77. https://doi.org/10. 1016/j.racreg.2011.03.005

Custodio, C., \& Metzger, D. (2014). Financial expert CEOs: CEO's work experience and firm's financial policies. Journal of Financial Economics, 114 (1), 125-154. https: //doi.org/10.1016/j.jfineco.2014.06.002

Czerney, K., Schmidt, J., \& Thompson, A. M. (2014). Does auditor explanatory language in unqualified audit reports indicate increased financial misstatement risk? The Accounting Review, 89 (6), 2115-2149. https://doi.org/10. 2308/accr-50836

Datta, D. R., \& Guthrie, J. P. (1994). Executive succession: organizational antecedents of CEO characteristics. Strategic Management Journal 15 (7), 569-577. https://doi. org/10.1002/smj.4250150706

Dechow, P. M., Sloan, R. G., \& Sweeney, A. P. (1995). Detecting earnings management. Detecting earnings management. The Accounting Review, 70, 193-225. https: //www.jstor.org/stable/248303

DeFond, M., \& Jiambalvo, J. (1991). Incidence and circum- 
stances of accounting errors. The Accounting Review, 66 (3), 643-655. https://www.jstor.org/stable/247814

DeFond, M., \& Zhang, J. (2014). A review of archival auditing research. Journal of Accounting and Economics, 58(23), 275-326. https://doi.org/10.1016/j.jacceco.2014. 09.002

Demerjian, P. R., Lev, B., Lewis, M. F., \& McVay, S. E. (2013). Managerial ability and earnings quality. The Accounting Review, 88 (2), 463-498. https://doi.org/10.2308/ accr-50318

Eilifsen, A., \& Messier, W. F. (2000). The incidence and detection of misstatements: A review and integration of archival research. Journal of Accounting Literature, 19 (1), $1-43$.

Ettredge, M., and Li, C., Wang, Q., \& Yang, X. (2018). Executive Director Financial Expertise and IPO Performance, Available at SSRN: https://ssrn.com/abstract $=2339276$.

Fama, E., \& Jensen, M. (1983). Separation of ownership and control. Journal of Law and Economics, 26, 301-325. https://www.jstor.org/stable/725104

Field, A. (2013). Discovering statistics using IBM SPSS statistics. Sage.

Francis, J., Huang, A. H., Rajgopal, S., \& Zang, A.Y. (2008). CEO reputation and earnings quality. Contemporary Accounting Research, 25 (1), 109-147. https://doi.org/10. 1506/car.25.1.4

General Accounting Office. (2002). Financial statement restatements: Trends, market impacts, regulatory responses and remaining challenges. GAO-03-138 (Washington, D.C).

Gounopoulosa, D., \& Pham, H. (2018). Financial expert CEOs and earnings management around initial public offerings. International Journal of Accounting, 53 (2), 102117. https://doi.org/10.1016/j.intacc.2018.04.002

Habib, A., \& Hossain, M. (2013). CEO/CFO characteristics and financial reporting quality: A review. Research in Accounting Regulation, 25 (1), 88-100. https://doi.org/10. 1016/j.racreg.2012.11.002

Hambrick, D. C., \& Mason, P. A. (1984). Upper echelons: The organization as a reflection of its top managers. The Academy of Management Review, 9 (2), 193-206. https: //doi.org/10.5465/amr.1984.4277628

Hambrick, D. C., Geletkanycz, M. A., \& Fredrickson, J. W. (1993). Top executive commitment to the status quo: some tests of its determinants. Strategic Management Journal, 14 (6), 401-418. https://doi.org/10.1002/smj. 4250140602

Hambrick, D. C. (2007). Upper echelons theory: An update. Academy of Management Review, 32, 334-343. https:// doi.org/10.5465/amr.2007.24345254

Hennes, K., Leone, A., \& Miller, B. (2008). The importance of distinguishing errors from irregularities in restatement research: The case of restatements and CEO/CFO turnover. The Accounting Review, 83 (6), 1487-1519. https://doi.org/10.2308/accr.2008.83.6.1487

Hermalin, B. E., \& Weisbach, M. S. (1998). Endogenously chosen boards of directors and their monitoring of the CEO. American Economic Review, 88 (1), 96-118. https: //www.jstor.org/stable/116820

Herrmann, P., \& Datta, D. K. (2002). CEO successor characteristics and the choice of foreign market entry mode: An empirical study. Journal of International Business Studies, 33(3), 551-569. https://doi.org/10.1057/palgrave.jibs. 8491031

Hesarzadeh, R., \& Bazrafshan, A. (2018). Corporate reporting readability and regulatory review risk. Baltic
Journal of Management. 13. https://doi.org/10.1108/ BJM-11-2017-0357.

Huang, H. W., Green, E. R., \& Lee, C. C. (2012) CEO Age and Financial Reporting Quality. Accounting Horizons, 26 (4), 725-740. https://doi.org/10.2308/acch-50268

Huang, S. K. (2013). The impact of CEO characteristics on corporate sustainable development. Corporate Social Responsibility and Environmental Management, 20, 234-244. https://doi.org/10.1002/csr.1295

Jensen, M. C., \& Meckling, W. H. (1976). Theory of the firm: Managerial behavior, agency costs and ownership structure. Journal of Financial Economics, 3(4), 305-360. https://doi.org/10.1016/0304-405X(76)90026-X

Ji, X, D., Lu, W., \& Qu, W. (2017). Voluntary disclosure of internal control weakness and earnings quality: evidence from China. The International Journal of Accounting, 52 (1), 27-44. https://doi.org/10.1016/j.intacc.2017. 01.007

Jiang, F., Zhu, B., \& Huang, J. (2013). CEO's financial experience and earnings management. Journal of Multinational Financial Management, 23 (3), 134-145. https: //doi.org/10.1016/j.mulfin.2013.03.005

Jiang, H., Habib, A., \& Zhou, D. (2015). Accounting restatements and audit quality in China. Advances in Accounting, 31 (1), 125-135. https://doi.org/10.1016/j.adiac.2015. 03.014

Jongjaroenkamol, P., \& Laux, V. (2017). Insider versus outsider CEOs, executive compensation, and accounting manipulation, Journal of Accounting and Economics, 63 (23), 253-261. https://doi.org/10.1016/j.jacceco.2017. 01.002

Kalelkar, R., \& Khan, S. (2016). CEO Financial Background and Audit Pricing. Accounting Horizons, 30 (3), 325-339. https://doi.org/10.2308/acch-51442

Kaplan, S., \& Minton, B. (2012). How has CEO turnover changed? Increasingly performance sensitive boards and increasingly uneasy CEOs, University of Chicago working paper.

Karaevli, A. (2007). Performance consequences of new CEO 'Outsiderness': Moderating effects of pre and postsuccession contexts. Strategic Management Journal, 28 (7), 681706. https://doi.org/10.1002/smj.589

Klein, A. (2002). Audit committee, board of director characteristics, and earnings management. Journal of Accounting and Economics, 33 (3), 375-400. https://doi.org/10. 1016/S0165-4101(02)00059-9

Kotter, J. P. (1982). General managers are not generalists. Organizational dynamics, 1982 (Spring), 5-19. https:// doi.org/10.1016/0090-2616(82)90026-2

Lai, S. M. \& Liu, C. L. (2018). The Effect of Auditor Characteristics on the Value of Diversification. Auditing: A Journal of Practice \& Theory, 37 (1), 115-137. https: //doi.org/10.2308/ajpt-51831

Larcker, D. F., \& Tayan, B. (2012). Is a powerful CEO good or bad for Shareholders? Stanford Closer Look Series. November 2012. Available at https://www.gsb.stanford.edu/sites/default/files/ publication-pdf/cgri-closer-look-28-powerful-ceo.pdf

Lauterbach, B., Vu. J., \& Weisberg, J. (1999). Internal vs. external successions and their effect on firm performance. Human Relations, 52 (12), 1485-1504. https://doi.org/ $10.1177 / 001872679905201201$

Lin, Y, CH., Wang, Y, CH., Chiou, J, R., \& Huang, H, W. (2014). CEO characteristics and internal control quality. Corporate Governance: An International Review, 22 (1), 24-42. 
http://dx.doi.org/10.1111/corg.12042

Liu, Y., \& Jiraporn, P. (2010). The impact of CEO power on bond ratings and yields. Journal of Empirical Finance, 17(4), 744-762. https://doi.org/10.1016/ j.jempfin.2010.03.003

MacKie-Mason, J. K. (1990). Do taxes affect corporate financing decisions? Journal of Finance, 45 (5), 1471-1491. https://doi.org/10.1111/j.1540-6261.1990.tb03724.x

Mashayekhi, B., \& Bazaz, M. S. (2008). Corporate governance and firm performance in Iran. Journal of Contemporary Accounting and Economics, 4 (2), 156-172. https: //doi.org/10.1016/S1815-5669(10)70033-3

Mashayekhi, B., \& Mashayekh, S. (2008). Development of accounting in Iran. The International Journal of Accounting, 43 (1), 66-86. https://doi.org/10.1016/j.intacc.2008. 01.004

Matsunaga, S.R. and Yeung, PE. (2008). Evidence on the impact of a CEO's financial experience on quality of the firm's financial reports and disclosures. Proceedings of the 2008 AAA Financial Accounting and Reporting Section Conference.

Matsunaga, S. R., Wang, S., Yeung, P. E. (2013). Does Appointing a Former CFO as CEO Influence a Firm's Accounting Policies? Working Paper University of Oregon.

Moayedi, V., \& Aminfard, M. (2012). Iran's post-war financial system. International Journal of Islamic Middle Eastern Financing and Management, 5, 264-281. https://doi.org/ 10.1108/17538391211255232

Oradi, J., and Izadi, Z, D, J. (2019). Audit committee gender diversity and financial reporting: evidence from restatements, Managerial Auditing Journal, 35(1), 67-92. https: //doi.org/10.1108/MAJ-10-2018-2048

Oradi, J., Asiaei, K., and Rezaee, Z. (2020). CEO financial background and internal control weaknesses, Corporate Governance: An International Review, 28 (2), 119-140. https://doi.org/10.1111/corg.12305

Palmrose, Z. V., Richardson, V., \& Scholz, S. (2004). Determinants of market reactions to restatement announcements. Journal of Accounting and Economics, 37 (1), 5989. https://doi.org/10.1016/j.jacceco.2003.06.003

Pfeffer, J., \& Salancik, G. R. (1978). The External Control of Organizations. Harper \& Row: New York.

Plumlee, M., \& Yohn, T. L. (2010). An analysis of the underlying causes attributed to restatements. Accounting Horizons, 24 (1), 41-64. https://doi.org/10.2308/acch.2010. 24.1.41

Presley, T. J., \& Abbott, L. J. (2013). AIA submission: CEO overconfidence and the incidence of financial restatement. Advances in accounting, 29 (1), 74-84. https: //doi.org/10.1016/j.adiac.2013.03.007

Rezaee, Z., \& Fogarty, T. (2019). Business Sustainability, Corporate Governance and Organizational Ethics. New Jersey, United States: John Wiley and Sons Inc.

Salehi, M., Lari, D. B, M., Naemi, M. (2018). The effect of CEO tenure and specialization on timely audit reports of Iranian listed companies. Management Decision, 56 (2), 311-328. https://doi.org/10.1108/MD-10-2017-1018

Schepker, D. J., Kim, Y., Patel, P. C., Thatcher, S. M. B., Campion, M. C. (2017). CEO succession, strategic change, and post-succession performance: A meta-analysis. The Leadership Quarterly, 28 (6), 701-720. https://doi.org/ $10.1016 /$ j.leaqua.2017.03.001

Schipper, K., \& Vincent, L. (2003). Earnings quality. Accounting Horizons, 17, 97-110. https://doi.org/10.2308/acch. 2003.17.s-1.97

Scholz, S. (2008). The changing nature and consequences of public company financial restatements: 1997-2006. Washington, D.C.: U.S. Department of the Treasury.

Sheikh, S. (2018). CEO power, product market competition and firm value. Research in International Business and Finance, 46, 373-386. https://doi.org/10.1016/j.ribaf. 2018.04.009

Sheikh, S. (2019). CEO power and corporate risk: The impact of market competition and corporate governance. Corporate Governance: An International Review, 27 (5), 341-357. https://doi.org/10.1111/corg.12285

Tushman, M. L., \& Romanelli, E. (1985). Organizational evolution: a metamorphosis model of convergence and reorientation. Research in Organizational Behavior, 7, 171222.

Vafeas, N. (2009). Is accounting education valued by the stock market? Evidence from corporate controller appointments. Contemporary Accounting Research, 26 (4), 1143-1174. https://doi.org/10.1506/car.26.4.6

Veprauskait, E., \& Adams, M. (2013). Do powerful chief executives influence the financial performance of UK firms? The British Accounting Review, 45 (3), 229-241. https: //doi.org/10.1016/j.bar.2013.06.004

Wang, D. (2006). Founding family ownership and earnings quality. Journal of Accounting Research, 44 (3), 619-656. https://doi.org/10.1111/j.1475-679X.2006.00213.x

Wiersema, M. F, \& Bantel, K. A. (1993). Top management team turnover as an adaptation mechanism: the role of the environment. Strategic Management Journal, 14 (7), 485-504. https://doi.org/10.1002/smj.4250140702

Wilson, W. M. (2008). An empirical analysis of the decline in the information content of earnings following restatements. The Accounting Review, 83 (2), 519-548. https: //doi.org/10.2308/accr.2008.83.2.519

Zhang, W. (2009). CEO tenure and earnings quality. Working Paper, School of Business, University of Texas, Dallas.

Zhang, H., Huang, H. G., \& Habib, A. (2018). The effect of tournament incentives on financial restatements: Evidence from China. The International Journal of Accounting, 53 (2), 118-135. https://doi.org/10.1016/j.intacc.2018. 05.002 